\title{
КОМПАРАТИВНІ КОНСТРУКЦІЇ ЯК ВЕРБАЛІЗАТОРИ КОНЦЕПТІВ УЧИТЕЛЬ ТА УЧЕНЬ (на матеріалі творів Івана Франка та Чарльза Діккенса)
}

\author{
ОКСАНА ДЗЮБЕНКО \\ Київський університет імені Бориса Грінченка, Київ - Україна \\ o.dziubenko@kubg.edu.ua; ORCID: 0000-0002-0816-602 \\ STRUKTURY PORÓWNAWCZE \\ JAKO WERBALIZATORY KONCEPTÓW NAUCZYCIEL I UCZEŃ \\ (na materiale utworów Iwana Franki \\ i Charlesa Dickensa) \\ OKSANA DZIUBENKO \\ Kijowski Uniwersytet imienia Borysa Hrinczenki, Kijów - Ukraina
} \begin{abstract}
dawcy i biorcy. Dzięki zestawieniu jednostek porównawczych wydzielono uniwersalne i etnokulturowe składniki ukraińskiej i angielskiej kultury językowej. standard obrazu.

\author{
SIMILES AS VERBALIZERS OF \\ THE TEACHER AND STUDENT CONCEPTS \\ (based on the novels of Ivan Franko \\ and Charles Dickens) \\ OKSANA DZIUBENKO
}

Borys Grinchenko Kyiv University, Kyiv — Ukraine
\end{abstract}

STRESZCZENIE. Artykuł poświęcono wyjaśnieniu konceptów NAUCZYCIEL i UCZEŃ na podstawie analizy struktur porównawczych w twórczości Iwana Franki i Charlesa Dickensa. Aparat terminologiczny w analizie porównawczej stanowią obrazy-etalony, strefy

Słowa kluczowe: projekt porównawczy, koncept, dyskurs, strefa dawcy, strefa biorcy,

\begin{abstract}
The article explores the explications of the TEACHER and STUDENT concepts based on the analysis of similes in the works of Ivan Franko and Charles Dickens. Terminological apparatus for the analysis of similes are model images, donor and recipient spheres. The universal and ethno-cultural components of the Ukrainian and British linguocultures are singled out based on the comparison of similes.

Key words: simile, concept, discourse, donor sphere, recipient sphere, model image.

$\mathrm{K}$ омпаративні конструкції (далі - КК) входять до системи понять, за допомогою яких носії мови класифікують і категоризують довкілля. Вони $\epsilon$ базовою частиною етномовної картини світу. М. Фуко твердив, що порівняння (схожість) — „найуніверсальніший, найочевидніший, але водночас і найбільш прихований елемент, що підлягає виявленню, що визначає форму пізнання [...] й гарантує багатство його змісту"1 (переклад автор. - О. Д.). Крім того, „Порівняння є емоційно-образною, стилістично насиченою та водночас економ-

\footnotetext{
${ }^{1}$ М. Фуко, Слова и вещи. Археология гуманитарных наук, СПб. 1994, с. 66.
} 
ною мовною одиницею"2. У руслі лінгвокультурології КК розглядаємо як мовну одиницю, що “дає змогу об'єднати різносторонні побудови в межах простого і складного речення, інтеграційним параметром яких виступає компаративна семантика"з, та, як правило, позначена культурним забарвленням. I. Сєченов щодо здатності свідомості до асоціацій зазначав: „Усе, що людина сприймає органами чуття, і все, що є результатом їі мисленнєвої діяльності (від цілісних картин світу до окремих ознак і властивостей, абстрагованих від реалій, до розчленованих конкретних вражень), може з'єднуватися в нашій свідомості асоціативно"4. Відтак дослідження КК у літературно-художньому дискурсі з погляду лінгвокультурології спрямоване на виявлення специфіки вибору асоціатів-еталонів концептів УЧИТЕЛЬ та УЧЕНЬ з певної донорської сфери англійської та української мов.

Мета наукової розвідки - здійснити порівняльний аналіз КК, що функціюють у текстах Івана Франка та Чарльза Діккенса, як експлікаторів концептів УЧИТЕЛЬ та УЧЕНЬ. Матеріал дослідження — твори Івана Франка (Борис Граб, Грищева шкільна наука, Малий Мирон, Причинки до автобіографії, Schönschreiben) та Чарльза Діккенса (David Copperfield, Dombey and Son, Hard Times), оскільки ці письменники яскраво репрезентують українську та британську лінгвокультури, працюють у межах реалізму в одному історичному періоді.

Аналіз текстів Івана Франка та Чарльза Діккенса дає змогу виділити реципієнтну сферу УЧИТЕЛЬ як найпоширеніше мовне втілення концепту УЧИТЕЛЬ. Для характеристики цієї реципієнтної сфери на прикладі КК виокремлюємо донорські сфери, що спільні для англійської та української лінгвоспільнот: ТВАРИНИ, ХИЖІ ПТАХИ, НЕГАТИВНІ КАЗКОВІ ГЕРОЇ, ВИДАТНІ ОСОБИСТОСТІ. Донорська сфера ТВАРИНИ в обох мовах має однакове образне наповнення: англ. a cart-horse ; $^{5}$ укр. кінь ${ }^{6}$. Донорська сфера ХИЖІ ПТАХИ подає різні образи-еталони для кожної аналізованої лінгвокультури: англ. a bird of ill-omen (... with her sable plumage and her hooked beak, like a bird of ill-omen...в траурному оперенні $і$ з гачкуватим носом, подібно до зловісної птиці (DDS, ch. 11); укр. орел (...і немов орел слідкує згори за добичею, так і він, озираючись по класу, зійшов із підвищеного градуса і почав свій обхід ${ }^{7}$. Зі сфери НЕГАТИВНІ КАЗКОВІ ІСТОТИ виокремили різні денотати-репрезентанти для англійської та української мов: англ. a Ghoul (They must be dead - stone dead - and then Miss Blimber dug them up like a Ghoul - Вони повинні бути мертвими безнадійно мертвими, - а тоді міс Блімбер викопає їх із могили, як вампір (DDS, ch. 11), a giant (Mr. Creakle entered after breakfast, and stood in the doorway

${ }^{2}$ Т. П. Па в л ю к, Концепт ЖІНКА у порівняльних конструкціях творів Лесі Українки, [в:] Система і структура східнослов'янських мов, зб. наук. праць до 175-річчя НПУ ім. М. П. Драгоманова, Київ 2010, с. 76.

3 Л. В. Прокопчук, Категорія порівняння та ї̈ вираження в структурі простого речення, дис... канд. філол. наук, Вінниця 2000, с. 12.

${ }^{4}$ И. М. Сеченов, Кому и как разрабатьвать психологию: Психологические этюды, СПб. 1873 , с. 190 .

5 Ch. Dickens, Dombey and Son, [v:] Electronic resource: http://www.gutenberg.org/ files/821/821-h/821-h.htm (28.06.2016) - далі поклик на це джерело подаємо в круглих дужках у тексті статті з використанням скорочення DDAS, біля якого подаємо вказівку на главу.

${ }^{6}$ І. Я. Франко, Причинки до автобіографї̈, [в:] Й ого ж, Зібр. творів, у 50 томах, Київ 1983 , т. 39 , с. 289 - далі поклик на це джерело подаємо в круглих дужках у тексті статті 3 використанням скорочення ФПДА, біля якого подаємо вказівку на сторінку.

${ }^{7}$ I. Я. Франко, Schönschreiben, [в:] Його ж, Зібр. творів, у 50 томах, Київ 1978, т. 15, c. 87 - далі поклик на це джерело подаємо в круглих дужках у тексті статті з використанням скорочення Schönschreiben, біля якого подаємо вказівку на сторінку. 
looking round upon us like a giant in a storybook surveying his captives - Micmep Крікл увійшов після сніданку і зупинився біля порога, озираючи нас, немов велетень з казки, який оглядає своїх бранщів ; укр. демон (...що в ньому криється щось злобне та завидюще, щось таке, як той демон (ФПДА, с. 291). Аналіз КК $з$ донорських сфер ТВАРИНИ, ХИЖІ ПТАХИ, НЕГАТИВНІ КАЗКОВІ ГЕРОЇ засвідчив, що реципієнтна субсфера УЧИТЕЛЬ має різко пейоративну конотацію. Зазначимо, що аналізованим КК властива кореляція концепту УчИТЕЛЬ з близькими етносами негативно забарвленими реаліями, зафіксованими в наївній свідомості.

Позитивно маркованими є денотати з донорської сфери РОДИННІ СТОСУНКИ. Еталони із цієї сфери виявили в літературних текстах двох досліджуваних лінгвокультур, напр.: укр. Борис, для якого Міхонський зробився правдивим духовим батьком 9 . За еталони зазвичай обирають осіб, які $є$ найближчими родичами та a priori сприймаються суспільством позитивно: батько, мати, брат.

Крім виділених донорських сфер, українська лінгвокультура для характеристики реципієнтної сфери УЧИТЕЛЬ оперує образами-еталонами зі сфер НЕГАТИВНІ АНТРОПОМОРФНІ ІСТОТИ, РЕЛІГІЯ та РОСЛИНИ. Найбільш чисельною семантичною групою є сфера НЕГАТИВНІ АНТРОПОМОРФНІ ICТОТИ, що представлена такими денотатами: грізний цар, божевільний, укротитель диких звірів, кат. Напр.: Він входив у клас, мов укротитель диких звірів y клітку, $і$ гуляв поміж нами, як необмежений пан наших тіл і душ (ФПДА, с. 297). Образи-еталони зі сфери РЕЛІГІЯ характеризуються позитивною конотацією, напр.: біблійний Саул (ФБГ, с. 179). Донорську сферу РОСЛИНИ реперезентує образ-еталон верба (Став чоловік тим учителем $і$ зараз, як та верба, мусив пустити коріння) ${ }^{10}$. Вибір еталонів цілком умотивований: верба - український національний символ ${ }^{11}$.

В англійській літературі зустрічаємо образи-еталони a cannon, a galvanizing apparatus, що належать до донорської сфери АРТЕФАКТИ: ...he seemed a kind of cannon loaded to the muzzle with facts, and prepared to blow them clean out of the regions of childhood at one discharge. He seemed a galvanizing apparatus, too, charged with a grim mechanical substitute for the tender young imaginations that were to be stormed away - ..він був схожий на гармату, до самого жерла начинену фактами, яка була готова одним пострілом вибити їх за межі дитинства. Він також видавався гальванічним приладом, зарядженим бездушною механічною силою, що повинна була розвіяти ніжну дитячу уяву (DDAS, ch. 2).

Звернімося до характеристики концепту УЧЕНЬ на прикладі образіветалонів у складі КК. Виокремлюємо реципієнтну сферу УЧЕНЬ як найпоширеніше мовне втілення концепту УЧЕНЬ. Літературно-художній дискурс англійської та української мов представлений спільними донорськими сферами ТВАРИНИ, ПТАХИ, ХВОРОБИ. Першою реакцією на аналізовану ознаку є до-

8 Ch. Dickens, David Copperfield, [v:] Electronic resource: http:/www.gutenberg.org/ files/766/766-h/766-h.htm (28.06.2016) — далі поклик на це джерело подаємо в круглих дужках у тексті статті з використанням скорочення DDC, біля якого подаємо вказівку на главу.

${ }^{9}$ І. Я. Франко, Борис Граб, [в:] Його ж, Зібр. творів, у 50 томах, Київ 1978, т. 18, c. 189 - далі поклик на це джерело подаємо в круглих дужках у тексті статті з використанням скорочення ФБГ, біля якого подаємо вказівку на сторінку.

${ }^{10}$ I. Я. Фран ко, Немає друга понадмудрість, [в:] Його ж, Зібр. творів, у 50 томах, Київ 1976, т. 2, с. 85 - далі поклик на це джерело подаємо в круглих дужках у тексті статті з використанням скорочення ФНДПМ, біля якого подаємо вказівку на сторінку.

${ }^{11}$ В. Жай в о р он ок, Знаки украӥнської етнокультури: словник-довідник, Київ 2006, с. $72-74$. 
норська сфера ТВАРИНИ. Універсальними для двох лінгвокультур є образиеталони укр. миші в пастиі (ФПДА, с. 307) / англ. a little mouse (DDAS, ch. 11), укр. ягнята / англ. a lamb (DDAS, ch. 11). Під час вибору еталонів для реципієнтної сфери УЧЕНЬ актуалізуються ознаки 'заляканість', 'незначущість', оскільки істоти малого розміру в народному світосприйнятті асоціюються з полохливістю, незначимістю. КК із цими еталонами наголошують на незначущій ролі особистості учня та описують систему освіти, що ігнорує індивідуальність учня. Напр., миша символізує боягузтво, безпорадність підвладних ${ }^{12}$, вівця - невинуватість, покірність ${ }^{13}$. Крім спільних еталонів, образ учня співвідноситься й з різними для кожної лінгвокультури денотатами: укр. слимак у своїй халабудиі (Жидок на прозвище Йонас Туртельтауб ... знітився $і$ скулився, як слимак у своїй халабудиі, і перестав писати (Schönschreiben, с. 88), теля (...а на логарифми буде дивитися, як теля на нові ворота (ФБГ, с. 179); англ. little hares (They had been lectured at, from their tenderest years; coursed, like little hares - Давати освіту їм почали від самого ніжного віку; ганяли як молодих зайців ${ }^{14}$, a donkey (I am a Donkey. ... I am more stupid than one - Я осел. ...Я ще дурніший, ніж осел (DHT, ch. 8). Домінантними семами, покладеними в основу створення цих КК, є 'заляканість', 'нерозумність', 'перевантаження'. Наведений ілюстративний матеріал свідчить, що за допомогою еталонів зі сфери ТВАРИНИ в літературно-художньому дискурсі, як правило, передається ознака 'важке становище'.

Наступна за кількісним показником сфера ХВОРОБИ. У складі КК творів Івана Франка виокремлено такі образи-еталони: лихоманка (Він раз у раз дрижав, мов у лихоманці (Schönschreiben, c. 88), сновида (...nрокляті професорські причинки та заохоти до науки так надойли йому, що він аж вихуд та поблід $i$ ходив увесь час, мов сновида ${ }^{15}$, недужий (У школі дитина хапатися буде науки на диво, впиватися буде нею, як недужий свіжим повітрям⿻ ${ }^{16}$. Серед проаналізованих КК у текстах Чарльза Діккенса можемо виокремити таку одиницю: Not with the brightness natural to cheerful youth, but with uncertain, eager, doubtful flashes, which had something painful in them, analogous to the changes on a blind face groping its way - Це було не те природне, веселе пожвавлення, яке властиве шасливому дитинству, але з боязкими, жадібними, сумнівними спалахами, з відтінком чогось болючого в них, як зміни на обличчі сліпого, що навпомачки йде по дорозі (DHT, ch. 3), у складі якої виділили образ-еталон a blind. Аналізовані КК негативно забарвлені: за допомогою еталонів зі сфери ХВОРОБИ письменники змальовують важке становище учнів і недосконалість освітньої системи.

Менш численна донорська сфера ПТАХИ, що оперує такими образамиеталонами: англ. melancholy pigeons (... and sometimes a dull crying of young gentlemen at their lessons, like the murmurings of an assemblage of melancholy

${ }^{12}$ Там с амо, с. 366.

13 Т ам с амо, c. 90.

${ }^{14} \mathrm{Ch}$. Dicken s, Hard Times, [v:] Electronic resource: http://www.gutenberg.org/files/786/786h/786-h.htm (28.06.2016) — далі поклик на це джерело подаємо в круглих дужках у тексті статті 3 використанням скорочення DHT, біля якого подаємо вказівку на главу.

${ }^{15}$ I. Я. Франко, Грицева шкільна наука, [в:] Його ж, Зібр. творів, у 50 томах, Київ 1978, т. 16, с. 182 - далі поклик на це джерело подаємо в круглих дужках у тексті статті з використанням скорочення ФГШН, біля якого подаємо вказівку на сторінку.

${ }^{16}$ I. Я. Франко, Малий Мирон, [в:] Його ж, Зібр. творів, у 50 томах, Київ 1978, т. 15, c. 71 - далі поклик на це джерело подаємо в круглих дужках у тексті статті з використанням скорочення ФММ, біля якого подаємо вказівку на сторінку. 
pigeons - ...а іноді глухе завивання юних джентльменів, які вчили урок, щуо нагадувало воркування зграї меланхолійних голубів (DDAS, ch. 11).

Крім поданих спільних донорських сфер, у кожній з аналізованих лінгвокультур виділяємо й образи-еталони зі сфер, що не виявляються в іншій. Напр.: у текстах Ч. Діккенса виокремили еталони з донорської сфери ПРИРОДНІ МАТЕРIАЛИ (wax (DHT, ch. 8), ashes (DDAS, ch. 7), у яких домінантним складником під час вибору еталона є сема 'блідість'. У текстах I. Франка виділяємо такі донорські сфери: НЕЖИВІ ІСТОТИ - мрец̧ь (Schönschreiben, с. 90); ПРИРОДНІ ЯВИЩА - буря (Schönschreiben, с. 89), туман (ФПДА, с. 298). Звернемо увагу на образ-еталон туман, під час проекції якого на реципієнтну сферу УЧЕНЬ актуалізуються семи 'темінь', 'незнання'. Наведені приклади засвідчують наявність негативнооцінних образів-еталонів в етнічній свідомості. Серед проаналізованих еталонів, що описують концепт УЧЕНЬ, у двох досліджуваних лінгвокультурах виявлено позитивно марковані одиниці та негативно забарвлені еталони на позначення відповідного становища учнів як об’єкта навчання.

Отже, у процесі аналізу КК в українському й англійському літературнохудожньому дискурсі виявляємо універсальні й етноспецифічні риси. Безумовно, образи-еталони культурно марковані, адже їхній вибір зумовлений об' єктами довкілля, що властиві відповідній етноспільноті. Унаслідок дослідження образіветалонів спільною рисою вважаємо високий ступінь активності зоонімів, орнітонімів та лексики зі сфери АРТЕФАКТИ у складі КК. Відмінність полягає й у тому, що вибір еталонів у межах цих сфер зумовлений різними образами, що пов' язано зі специфічним баченням світу кожною етноспільнотою.

\section{Список використаної літератури}

Жайворонок В., Знаки української етнокультури: словник-довідник, Київ 2006.

Павлюк Т. П., Конщепт ЖІНКА у порівняльних конструкиіях творів Лесі Українки, [в:] Система і структура східнослов'янських мов, зб. наук. праць до 175-річчя НПУ ім. М. П. Драгоманова, Київ 2010.

Прокопчук Л. В., Категорія порівняння та ї̈ вираження в структурі простого речення, дис... канд. філол. наук, Вінниця 2000.

Сеченов И. М., Кому и как разрабатывать психологию: Психологические этюды, СПб. 1873.

Франко I. Я., Борис Граб, [в:] Його ж, Зібр. творів, у 50 томах, Київ 1978, т. 18.

Франко І. Я., Грицева шкільна наука, [в:] Його ж, Зібр. творів, у 50 томах, Київ 1978, т. 16.

Франко І. Я., Малий Мирон, [в:] Його ж, Зібр. творів, у 50 томах, Київ 1978, т. 15.

Франко І. Я., Немає друга понад мудрість, [в:] Його ж, Зібр. творів, у 50 томах, Київ 1976, т. 2.

Франко І. Я., Причинки до автобіографії, [в:] Його ж, Зібр. творів, у 50 томах, Київ 1983 , т. 39.

Франко I. Я., Schönschreiben, [в:] Його ж, Зібр. творів, у 50 томах, Київ 1978, т. 15.

Фуко М., Слова и вещи. Археология гуманитарных наук, СПб. 1994.

Dickens Ch., David Copperfield, [v:] Electronic resource: http://www.gutenberg.org/ files/766/766-h/766-h.htm (28.06.2016).

Dickens Ch., Dombey and Son, [v:] Electronic resource: http://www.gutenberg.org/ files/821/821-h/821-h.htm (28.06.2016).

Dickens Ch., Hard Times, [v:] Electronic resource: http://www.gutenberg.org/files/786/786h/786-h.htm (28.06.2016). 


\section{Spysok vykorystanoi literatury \\ [References]}

Zhaivoronok V., Znaky ukrainskoi etnokultury: slovnyk-dovidnyk [Signs of Ukrainian Ethnoculture: Dictionary-Reference Book], Kyiv 2006.

Pavliuk T., Koncept ZHINKA u porivnialnykh konstruktsiiakh tvoriv Lesi Ukrainky [WOMAN in Comparative Constructions of Lesya Ukrainka's Works], [v:] Systema i struktura skhidnoslovsansky 'kh mov, zb. nauk. pracz' do 175-richchya NPU imeni M. P. Dragomanova, Kyiv 2010.

Sechenov I., Komy i kak razrabatyvat psihologiju: Psihologicheskije etiudy [Who and how is Supposed to Elaborate Psychology: Psychological Sketches], SPb. 1873.

Franko I., Borys Grab [Borys Grab], [v:] Jogo zh, Zibr. tvoriv, u 50 tomakh, Kyiv 1978, t. 18.

Franko I., Hrytseva shkilna nauka [Hrytsev's School Lessons of Life], [v:] Jogo zh, Zibr. tvoriv, u 50 tomakh, Kyiv 1978, t. 16.

Franko I., Malyj Myron [Little Myron], [v:] Jogo zh, Zibr. tvoriv, u 50 tomakh, Kyiv 1978, t. 15.

Franko I., Nemaye druha ponad mudrist [There is no Friend above Wisdom], [v:] Jogo zh, Zibr. tvoriv, u 50 tomakh, Kyiv 1976, t. 2.

Franko I., Prychynky do avtobiografiyi [Reasons for Autobiography], [v:] Jogo zh, Zibr. tvoriv, u 50 tomakh, Kyiv 1983, t. 39.

Franko I., Schönschreiben, [v:] Jogo zh, Zibr. tvoriv, u 50 tomakh, Kyiv 1978, t. 15.

Fuko M., Slova i veshchi [Words and Things]. Arheologija gumanitarnyh nauk, SPb. 1994.

Dickens Ch., David Copperfield, [v:] Electronic resource: http://www.gutenberg.org/ files/766/766-h/766-h.htm (28.06.2016).

Dickens Ch., Dombey and Son, [v:] Electronic resource: http://www.gutenberg.org/ files/821/821-h/821-h.htm (28.06.2016).

Dickens Ch., Hard Times, [v:] Electronic resource: http:/www.gutenberg.org/files/786/786h/786-h.htm (28.06.2016). 